\title{
ANALISIS PERILAKU BERBELANJA ONLINE KONSUMEN MUSLIM DALAM PERSPEKTIF GENDER DI PROVINSI RIAU (Ditinjau dari Perceived Risk, Service Infrastructure, dan Acquisition Utility)
}

\author{
Fakhrurrozi dan Alchudri \\ Fakultas Ekonomi UIN Suska Riau \\ Email: ozi_hsb@yahoo.com
}

\begin{abstract}
This study aims to determine the effect of perceived risk, service infrastructure, acquisition utility to the online shopping behavior of students in the province of Riau and to determine differences in perceived risk, service infrastructure, acquisition utility and online shopping behavior between male students and female in Riau Province. The total sample is 250 respondents. Independent variable is perceived risk $\left(X_{1}\right)$, service infrastruktur $\left(X_{2}\right)$, acquistion utility $\left(X_{3}\right)$ and dependen variavle is online shopping behavior $(Y)$. Data analysis using multiple linear regression analysis and one way ANOVA. The results showed perceived risk influence on online shopping behaviour, service infrastructure influence on online shopping behaviour, acquisition utility influence on online shopping behaviour, results of hypothesis testing using ANOVA showed that there are differences in perceived risk, service infrastructure, acquisition utility and online shopping behavior between male students and female students.
\end{abstract}

Keywords: Online purchase, perceived risk, service infrastructure, acquisition utility.

\section{PENDAHULUAN}

Dewasa ini trend belanja online terus meningkat, namun di sisi lain peluang munculnya kejahatan di dunia maya sangat merugikan konsumen maupun pihak toko online yang akan menjual produknya. Potensi kejahatan tersebut berupa penipuan, pembajakan kartu kredit maupun transfer dana illegal. Selain berbagai manfaat dalam berbelanja online (misalnya hemat tenaga, mengurangi kerepotan, mudah membandingkan harga dan hemat waktu), disisi lain, terdapat pula berbagai risiko yang melekat dari berbelanja online. Berbagai resiko yang terjadi dalam pembelian produk secara online dapat dikategorikan dalam dua kemungkinan yaitu resiko produk dan resiko transaksi. Resiko produk mengacu pada ketidakpastian pembelian akan memenuhi tujuan dari pembelian. Hal ini terjadi karena dalam pembelian secara online, pelanggan tidak bisa meraba, mencium, mencoba dan merasakan produk yang akan dibeli. Resiko transaksi mengacu kepada ketidakpastian atas segala sesuatu yang tidak terduga dan kurang baik sepanjang proses transaksi. Hal ini terjadi karena mekanisme pembayaran dalam transaksi online mengharuskan pelanggan mentransfer uang terlebih dahulu sebelum produk diterima. Selain faktor resiko, faktor kepercayaan terhadap situs belanja yang bersangkutan harus dipenuhi ketika seorang konsumen hendak memutuskan untuk berbelanja online. Kepercayaan merupakan salah satu faktor penentu yang penting bagi keberhasilan situs web untuk dapat bersaing di pasar online.

Dari sisi gender, beberapa penelitian menemukan bahwa terdapat perbedaan 
sikap antara pria dan perempuan dalam pengambilan keputusan berbelanja online. Menurut Bae dan Lee, sejak kehadiran internet, gender gap telah muncul khususnya dalam berbelanja online. Perempuan pada umumnya mempersepsikan risiko dalam berbelanja online yang lebih tinggi daripada laki-laki. Temuan ini mengkonfirmasi temuan sebelumnya yang telah dilakukan pada tahun 2004 oleh Garbarino dan Strahilevitz. Selain dari kedua penelitian tersebut, penelitian dari Jen-Hung dan YiChun lebih jauh mengeksplorasi bahwa perbedaan antara perempuan dan laki-laki dalam berbelanja online adalah dari sisi motivasinya dimana perempuan lebih menekankan pada motivasi hedonis (petualangan, sosialita, fashion, dan nilai) dibandingkan motivasi utilitarian (kenyamanan, kurangnya sosialita, dan hemat biaya).

Secara empirik terdapat beberapa faktor yang mempengaruhi keputusan berbelanja online. Sinha dan Kim menyatakan bahwa perilaku berbelanja online dipengaruhi oleh sikap yang dipengaruhi pula oleh perceived risk dan service infrastructure, sementara itu, Campo dan Bruegelmans menyatakan acquisition utility dapat mempengaruhi keputusan pembelian baik pada toko offline maupun online. Mengingat penggunaan internet dan e-commerce merupakan sesuatu yang sangat berkembang pesat dan menjadi suatu keniscayaan dimasa mendatang, maka dirasa penting untuk meneliti perilaku konsumen dalam menggunakan internet untuk berbelanja online. Sebagaimana telah dipaparkan sebelumnya, berbelanja online akan sangat terkait dengan adanya berbagai risiko yang melekat dari transaksi online tersebut sehingga dirasa perlu mendapatkan perhatian khusus. Penelitian ini menggabungkan variabel dari kedua penelitian sebelumnya dan menambahkan pula pengujian dari perspektif gender untuk mendapatkan hasil penelitian yang lebih komprehensif.

Dalam penelitian ini, penulis mengkaji tentang perilaku berbelanja online konsumen muslim dalam perspektif gender di Provinsi Riau (ditinjau dari perceived risk, service infrastructure, acquisition utility). Permasalahan yang menjadi fokus kajian adalah apakah perceived risk, service infrastructure, acquisition utility berpengaruh terhadap perilaku berbelanja online mahasiswa di Provinsi Riau? dan apakah ada perbedaan perceived risk, service infrastructure, acquisition utility dan perilaku berbelanja online antara mahasiswa laki-laki dan perempuan di Provinsi Riau?

\section{E-Commerce}

Definisi e-commerce bisa ditinjau dari 5 perspektif yaituºnline purchasing yaitu system yang memungkinkan pembelian dan penjualan produk dan informasi melalui 
internet dan jasa online lainnya, digital communication yaitu system yang memungkinkan pengiriman informasi digital, produk, jasa dan pembayaran online, service perspective yaitusystem yang memungkinkan upaya menekankan kualitas produk dan informasi terkini, business process yaitu system yang memungkinkan otomisasi transaksi dan aliran kerja, market-of-one perspective yaitu system yang memungkinkan proses "customization" produk dan jasa untuk diadaptasikan pada kebutuhan dan keinginan setiap pelanggan secara efisien.

$$
\text { Jenis-jenis }
$$

E-commerce

yaitu ${ }^{2}$ collaborative commerce (C-commerce) yaitu kerjasama secara elektronik antara rekan bisnis. Kerja sama ini biasanya terjadi antara rekan bisnis yang berada pada pada jalur penyediaan barang (supplay chain), Business-to-Consumers (B2C) yaitu penjual adalah suatu organisasi dan pembeli adalah individu, Consumer-to-Business (C2B) dimana konsumen memberitahukan barang atau layanan yang dibutuhkannya, selanjutnya organisasi-organisasi bersaing untuk menyediakan barang atau layanan tersebut kepada konsumen, Consumer-to-Consumer yaitu penjualan barang atau layanan antara individu, intrabusiness (intraorganizational) commerce dimana organisasi menggunakan $e$ commerce untuk meningkatkan kegiatan operasi organisasinya, Government-to-Citizens (G2C) and to Others yaitu pemerintah menyediakan layanan kepada masyarakat melalui teknologi e-commerce, Mobile Commerce (M-commerce) yaitu ecommerceyang dilaksanakan pada lingkungan tanpa kabel (wireless environment), seperti menggunakan telepon seluler untuk akses internet.

Pengertian dari e-commerce menurut Kalakota dan Whinston (Suyanto, 2003) dapat ditinjau dalam 4 perspektif berikut yaitu $^{3}$ : (1) dari perspektif komunikasi adalah pengiriman barang, layanan, informasi atau pembayaran melalui jaringan komputer atau melalui peralatan elektronik lainnya, (2) dari perspektif proses bisnis adalah aplikasi dari teknologi yang menuju otomatisasi dari transaksi bisnis dan aliran kerja, (3) dari perspektif layanan merupakan suatu alat yang memenuhi keinginan perusahaan, konsumen dan manajemen untuk memangkas biaya layanan (service cost) ketika meningkatkan kualitas barang dan meningkatkan kecepatan layanan pengiriman, (4) dari perspektif online, ecommerce menyediakan kemampuan untuk membeli dan menjual barang ataupun informasi melalui internet dan sarana online berikutnya.

\section{Perceived Risk}

Perceived risk berarti kenyakinan subyektif individu tentang potensi konsekuensi negatif dari keputusan yang diambil konsumen4. Persepsi risiko dibentuk oleh privasi, keamanan, dan kepercayaan ${ }^{5}$. Persepsi risiko dipandang sebagai 
ketidakpastian dihubungkan dengan hasil dari suatu keputusan6. Dalam literature $e$ commerce, ada dua kategori risiko yaitu: risiko transaksi dan risiko produk7.

Risiko transaksi adalah ketidakpastian sesuatu yang tak terduga dan kurang baik sepanjang proses transaksi. Risiko transaksi termasuk pembuktian, privasi, keamanan. Risiko transaksi mengacu pada ketidak pastian identitas pembuktian penjual tidak diungkapkan. Risiko privasi mengacu pada kemungkinan pencurian informasi pribadi ${ }^{8}$. Orang dapat dipercaya setia berhubungan dengan keselamatan data yang dipancarkan internet.

Dimensi perceived risk dalam online shopping adalah sebagai berikut9: (1) fraud risk yang mengacu pada perhatian konsumen mengenai kepercayaan terhadap penjual pada online shopping, (2) delivery risk yang mengacu pada perhatian konsumen mengenai proses pengiriman barang, (3) financial risk yang mengacu pada perhatian konsumen mengenai kemungkinan kehilangan uang ketika berbelanja melalui internet, (4) process dan time risk yang mengacu pada pandangan terhadap waktu, kemudahan dan kenyamanan konsumen mengenai berbelanja melalui internet, (5) product risk yang mengacu pada kualitas produk, kinerjanya, kepalsuan produk dan masalah lain dan berhubungan dengan produk tersebut, (6) privacy risk yang mengacu pada perhatian konsumen mengenai keamanan dari informasi pribadi ketika berbelanja secara secara online, (7) information risk yang mengacu pada perhatian konsumen terhadap ketidakpuasan informasi mengenai penjual ataupun produk.

\section{Service Infrastructure}

Tantangan terhadap berkembangnya e-commerce di negara-negara berkembang adalah kurangnya infrastruktur telekomunikasi di negara tersebut misalnya penggunaan komputer yang masih rendah dengan kurangnya sumber daya manusia yang berkualitas untuk mengembangkan dan mendukung e-commerce. Hal-hal yang terkait dengan pelayanan infrastruktur ini berhubungan dengan pengiriman produk yang dipesan, seperti pengiriman biaya, pengiriman tertunda atau tidak menerima produk dipesan. Sehingga pembeli online terpaksa memilih jasa pengiriman yang mahal agar proses pengiriman lebih aman.

Dalam hal pelayanan belanja online, faktor kemudahan pengembalian barang sering menjadi perhatian oleh para pembeli. Pelayanan pengembalian barang dilihat dari cara pertukaran produk, lamanya waktu diperbolehkan untuk kembali produk, dan biaya yang terkait dengan pengiriman barang kembali ke toko online.

Service and infrastructure terdiri dari pengiriman dan kebijakan pengembalian ${ }^{10}$.

\section{Acquisition Utility}

Acquisition utility adalah manfaat yang diterima konsumen dalam berbelanja 
online misalnya, kualitas produk, promosi, biaya (harga) yang dibutuhkan ketika memperoleh produk. Kajian tentang perilaku berbelanja telah ditunjukkan dalam teori bauran pemasaran seperti faktor harga yang merupakan faktor penting yang menentukan keputusan memilih sebuah toko. Seperti telah diketahui bahwa meskipun toko online maupun toko konvensional memiliki rantai yang sama dalam hal harga / kualitas, instrumen bauran pemasaran masih dapat berbeda untuk beberapa alasan.

Aspek-aspek acquisition utility terdiri dari11: (1) perbedaan aneka jenis barang.Banyaknya aneka pilihan jenis barang online dan offline dapat berbeda karena beberapa alasan. Di satu sisi, toko online memberikan kesempatan untuk membawa berbagai besar barang karena rak yang tidak terbatas di toko online. Di sisi lain, biaya dan kendala permintaan, waktu pengiriman dijadikan alasan untuk membatasi aneka jenis barang online untuk beberapa kategori (seperti bahan makanan), (2) perbedaan harga.Penjual online dapat menentukan harga yang berbeda di toko online mereka berdasarkan biaya dan permintaan. Toko online memerlukan tambahan biaya operasional, seperti untuk kemasan atau biaya pengepakan dan biaya pengiriman. Namun selain itu toko online dapat melakukan penghematan biaya dalam hal biaya tata letak toko, display dan biaya pembuatan rak yang lebih rendah, (3) perbedaan promosi.Intensitas kegiatan promosi berbeda antara toko online dengan toko konvensional dari penjual yang sama dalam rangka untuk memperhitungkan perbedaan dalam sensitivitas harga / promosi, atau karena alasan yang lebih pragmatis seperti manajer akun yang berbeda yang bertanggung jawab atas perencanaan promosi di setiap toko. Konsumen dapat bersikap dengan menentukan ketertarikan mereka pada kegiatan promosi yang lebih menarik antara toko online atau toko konvensional, stimuli toko.Di dalam stimuli toko atau iklan di toko dapat memicu kebutuhan untuk membeli suatu barang. Dibandingkan dengan toko konvensional, pembeli online cenderung kurang sensitif terhadap rangsangan atau stimuli dalam toko untuk beberapa alasan, seperti mereka dapat lebih mudah mengontrol mengklik atau memilih halaman kategori yang diinginkan, mereka tidak perlu antri di counter.

\section{Perilaku Konsumen}

Studi perilaku konsumen merupakan proses ketika individu atau kelompok menyeleksi, membeli, menggunakan atau membuang produk, pelayanan, ide dan pengalaman untuk memuaskan kebutuhannya ${ }^{12}$. Perilaku konsumen mencerminkan totalitas keputusan konsumen sehubungan dengan akuisisi, konsumsi, dan disposisi barang, jasa, kegiatan, pengalaman, orang, dan ide-ide oleh manusia dalam 
pengambilan keputusan dari waktu ke waktu.

Elemen utama dalam kerangka kerja konseptual perilaku konsumen ada empat, yaitu : efeksi (affect) dan kognisi (cognition), perilaku (behavior), lingkungan, strategi pemasaran (marketing strategy).

Tingkatan unit analisis perilaku konsumen terdiri atas 5 tipe yaitu : (1) konsumen di pasar, (2) konsumen sebagai individu yang terdiri dari persepsi, pembelajaran, nilai dan motivasi, kepribadian dan gaya hidup, sikap, perubahan sikap dan komunikasi interaktif, (3) konsumen sebagai pengambil keputusan terdiri dari pengambil keputusan individu, (4) konsumen dan budaya yang terdiri dari pendapatan dan kelas sosial, etnik, rasial, kebudayaan dan agama, (5) konsumen dan budaya.

\section{Keputusan Pembelian}

Pengambilan keputusan konsumen adalah pengintegrasian yang mengkombinasikan pengetahuan untuk mengevaluasi dua atau lebih perilaku alternatif dan memilih salah satu diantaranya. Hasil dari pengintegrasian ini adalah suatu pilihan yang disajikan secara kognitif sebagai keinginan berperilaku.

Keputusan membeli adalah pemilihan dari dua atau lebih alternatif pilihan yang ada, artinya bahwa syarat seseorang dapat membuat keputusan haruslah tersedia beberapa alternatif pilihan ${ }^{13}$.

Keputusan pembelian konsumen adalah membeli merek yang paling disukai dari berbagai alternatif yang ada, tetapi dua faktor bisa berada antara niat pembelian dan keputusan pembelian. Faktor pertama adalah sikap orang lain dan faktor yang kedua adalah faktor situasional. Oleh karena itu, preferensi dan niat pembelian tidak selalu menghasilkan pembelian yang aktual ${ }^{14}$.

\section{Perilaku Belanja Online}

Belanja melalui media internet sebagai pertukaran atau aktivitas komputer yang dilakukan seorang konsumen melalui alat penghubung komputer sebagai dasarnya, dimana komputer konsumen terhubung dengan internet dan bisa beinteraksi dengan retailer atau toko maya yang menjual produk atau jasa melalui jaringan ${ }^{15}$. Online shopping atau biasa juga disebut internet shopping merupakan proses dari pembelian produk atau jasa melalui internet ${ }^{16}$.

Dalam model perilaku konsumen online menerangkan faktor-faktor yang mempengaruhi keputusan pembelian konsumen dan prosesnya sebagai berikut ${ }^{17}$ : (1) keputusan membeli konsumen secara online sebagai variabel tergantung dipengaruhi oleh dua variabel yang tidak dapat dikendalikan sebagai variable bebas, yaitu variabel pertama meliputi: karakteristik 
konsumen, lingkungan serta penjual dan perantara. Variabel kedua meliputi karakteristik produk atau jasa dan sistem dalam e-commerce. Kedua variabel bebas yang tidak dapat dikendalikan itu mempengaruhi keputusan membeli konsumen online. (2) keputusan membeli konsumen meliputi: maksud, pembelian dan pembelian ulang. (3) karakteristik konsumen meliputi: umur, gender, etnik, pendidikan, masalah psikologi, pengetahuan, nilai-nilai yang dianutnya, kepuasan, pengalaman sebelumnya, preferensi, kebiasaan, kepercayaan, sikap, inovasi dan kepribadian. (4) karakteristik lingkungan meliputi: budaya, pengaruh sosial yang bersifat normatif, pengaruh sosial yang bersifat informasional, hukum, institusional, pemerintah, regulasi dan politik. (5) karakteristik penjual dan perantara: reputasi merek, kepercayaan, kebijakan dan prosedur, kompensasi dan apologi. (6) karakteristik produk atau jasa meliputi: pengetahuan mengenai produk atau jasa, tipe produk atau jasa, ketersediaan produk atau jasa, penyesuaian produk atau jasa, kualitas produk atau jasa, variasi produk atau jasa, diferensiasi produk atau jasa, frekuensi pembelian, tangibilitas, harga dan merek.

\section{METODE}

Penelitian ini dilaksanakan di seluruh Universitas di Provinsi Riau yaitu Universitas Riau, Universitas Islam Negeri
Sultan Syarif Kasim Riau, Universitas Islam Riau, Universitas Lancang Kuning, Universitas Abdurrab, Universitas Muhammadiyah Riau, Universitas Islam Indragiri, Universitas Pasir Pangaraian dan Universitas Islam Kuantan Singingi dengan menggunakan metode analisis analisis regresi linier berganda dan One Way ANOVA. Populasi adalah seluruh mahasiswa universitas di Provinsi Riau dan jumlah sampel sebanyak 250 responden (purposive sampling).

Teknik pengambilan data yang digunakan dalam penelitian ini adalah kuesioner. Kuesioner sebagai instrumen pengumpulan data, disusun dengan menggunakan skala Likert. Setiap pertanyaan mempunyai lima alternatif jawaban. Maka untuk itu ditetapkan bobot bagi alternatif jawaban yang dipilih. Alternatif jawaban pertama (a) diberi skor 5, alternatif jawaban kedua (b) diberi skor 4, alternatif jawaban ketiga (c) diberi skor 3, alternatif jawaban keempat (d) diberi skor 2, alternatif jawaban kelima (e) diberi skor 1 .

Sebelum penelitian dilakukan, dilakukan pengujian terhadap validitas dan reliabilitas terhadap daftar pertanyaan yang digunakan.

Variabel penelitian terdiri dari variabel bebas yaitu perceived risk $\left(\mathrm{X}_{1}\right)$, service infrastruktur $\left(\mathrm{X}_{2}\right)$, acquistion utility $\left(\mathrm{X}_{3}\right)$ dan variable terikat yaitu perilaku berbelanja online $(\mathrm{Y})$. 
Teknik analisis data yang digunakan dalam penelitian ini adalah analisis regresi linier berganda dan One Way ANOVA. Regresi linier berganda digunakan untuk menganalisis hubungan maupun pengaruh dari beberapa variabel dan One Way ANOVA untuk uji beda.

\section{HASIL PENELITIAN}

Gambaran mengenai variablevariabel penelitian yaitu perceived risk, service infrastructure, acquisition utility sebagai variabel independen dan perilaku berbelanja online sebagai variabel dependen yang disajikan dalam table descriptive statistics. Tabel descriptive statistics menunjukkan angka minimum, maksimum, mean dan standar deviasi dari penyebaran data hasil rekap kuesioner yang dapat dilihat pada table berikut ini :

Tabel 1.

Statistik Deskriptif

Descriptive Statistics

\begin{tabular}{|c|c|c|c|c|c|}
\hline & $\mathrm{N}$ & Minimum I & Maximum & Mean & Std. Deviation \\
\hline Perceived Risk & 250 & 26.00 & 52.00 & 42.3400 & 7.11639 \\
\hline Service Infrastructure & 250 & 32.00 & 60.00 & 50.4560 & 7.96932 \\
\hline Acquisition Utility & 250 & 20.00 & 65.00 & 52.3080 & 9.02680 \\
\hline Perilaku Berbelanja & 250 & 8.00 & 29.00 & 22.6760 & 3.57634 \\
\hline Valid N (listwise) & 250 & & & & \\
\hline
\end{tabular}

Sumber: Output SPSS (data diolah)

Berdasarkan pengujian statistik diketahui bahwa nilai minimum variabel perceived risk sebesar 26, nilai maksimum 52 dan nilai rata-rata (mean) sebesar 42,3400 dengan standar deviasi sebesar 7,12. Nilai rata-rata dan nilai standar deviasi perceived risk ini menunjukkan bahwa terdapat penyebaran data yang baik karena nilai rataratanya lebih besar dari pada nilai standar deviasinya.

Kemudian variabel service infrastructure memperoleh nilai minimum sebesar 32, nilai maksimum 60 dan nilai rata- rata (mean) sebesar 50,4560 dengan standar deviasi sebesar 7,97. Nilai rata-rata dan nilai standar deviasi service infrastructure ini menunjukkan bahwa terdapat penyebaran data yang baik karena nilai rata-ratanya lebih besar dari pada nilai standar deviasinya.

$$
\text { Variabel acquisition utility }
$$

memperoleh nilai minimum sebesar 20 , nilai maksimum 65 dan nilai rata-rata (mean) sebesar 52,3080 dengan standar deviasi sebesar 9,03. Nilai rata-rata dan nilai standar deviasi acquisition utility ini menunjukkan bahwa terdapat penyebaran data yang baik 
karena nilai rata-ratanya lebih besar dari pada nilai standar deviasinya.

Variabel perilaku berbelanja online memperoleh nilai minimum sebesar 8 , nilai maksimum 29 dan nilai rata-rata (mean) sebesar 22,6760 dengan standar deviasi sebesar 3,58. Nilai rata-rata dan nilai standar deviasi perilaku berbelanja online ini menunjukkan bahwa terdapat penyebaran data yang baik karena nilai rata-ratanya lebih besar dari pada nilai standar deviasinya.

Dari statistik deskrptif tersebut, dapat disimpulkan bahwa secara keseluruhan nilai rata-rata variabel perceived risk, service infrastructure, acquisition utility dan perilaku berbelanja online lebih besar dari besar dari pada standar deviasinya.

\section{Uji Normalitas}

Uji normalitas bertujuan untuk mengetahui apakah distribusi sebuah data mengikuti atau mendekati distribusi normal. Data yang baik adalah yang mempunyai pola seperti distribusi normal (tidak melenceng ke kiri dan ke kanan). Dari hasil pengolahan data dengan metode SPSS dapat dikemukakan bahwa nilai-nilai sebaran data terletak di sekitar garis lurus, sehingga persyaratan normalitas dapat dipenuhi seperti terlihat pada lampiran.

\section{Uji Validitas}

Uji validitas daftar pertanyaan dilakukan dengan tujuan untuk mengetahui kehandalan angket. Kehandalan angket mempunyai arti bahwa angket mampu mengukur apa yang seharusnya diukur. Dari hasil pengolahan data mengenai indikatorindikator yang diteliti, diperoleh hasil bahwa semua butir pertanyaan adalah valid karena lebih besar dari $r$ tabel.

\section{Uji Reliabilitas}

Setelah dilakukan uji validitasnya kemudian perlu diketahui uji reliabilitas. Uji reliabilitas ini ditunjukkan dari hasil koefisien Alpha Cronmbach dengan hasil. Nilai Alpha ini >0,6 yang dapat dikatakan bahwa dari seluruh indikator memiliki reliabilitas yang tinggi.

\section{Uji Multikolinearitas}

Uji multikolinearitas bertujuan untuk menguji apakah dalam suatu model regresi ditemukan adanya korelasi antar variabel bebas penelitian.Model regresi yang baik seharusnya tidak terjadi korelasi diantara variabel bebas.Ada tidaknya korelasi antar variabel tersebut dapat dideteksi dengan melihat nilai variance Inflation Factor (VIF).

VIF merupakan kebalikan dari tolerance jika nilai tolerance yangrendah sama dengan nilai VIF tinggi (karena VIF = tolerance). Cara umum yang dipakai untuk menunjukkan multikolinearitas adalah jika nilai tolerance $<0,10$ atau sama dengan VIF $>$ 10,00 maka terjadi multikolinearitas dalam penelitian ini. Hasil uji multikolinearitas dapat dilihat tabelberikut : 
Tabel 2.

Hasil Uji Multikolinearitas

\begin{tabular}{|c|c|c|c|}
\hline \multirow{2}{*}{ Model } & \multicolumn{2}{|c|}{ Colinearity Statistics } & \multirow{2}{*}{ Keterangan } \\
\hline & Tolerance & VIF & \\
\hline Perceived risk & 0,974 & 1,027 & Bebas multikolinearitas \\
\hline Service infrastructure & 0,959 & 1,043 & Bebas multikolinearitas \\
\hline Acquisition utility & 0,954 & 1,048 & Bebas multikolinearitas \\
\hline
\end{tabular}

Sumber: Output SPSS (data diolah)

Berdasarkan hasil pada tabel di atas dapat diketahui bahwa hasil uji multikolinearitas seluruh variabel memiliki nilai tolerance berada di atas atau $>0,10$ dan nilai VIF di bawah atau $<10,00$. Jadi disimpulkan bahwa model regresi bebas dari pengaruh multikolinearitas.

\section{Uji Autokorelasi}

Autokorelasi adalah hubungan atau korelasi antara data yang satu dengan data yang lainnya dalam satu variabel.Autokorelasi ini dapat terjadi pada variabel dependen atau variabel independen (karena terdapat dalam satu lajur).Teknik pengujian autokorelasi adalah Durbin-Watson Test.

Uji autokorelasi bertujuan menguji apakah model regresi linier ada korelasi antara kesalahan pengganggu pada periode $t$ dengan kesalahan pengganggu pada periode sebelumnya ( $\mathrm{t}-1$ ).Jika terjadi korelasi, maka dalam hal ini terdapat problem autokorelasi.

Hasil pengujian autokorelasi dari penelitian ini dapat dilihat dari tabel berikut:

Tabel 3.

Hasil Uji Autokorelasi

\begin{tabular}{ccc}
\hline Durbin-Watson & n & Keterangan \\
\hline 2,109 & 250 & Tidak terdapat autokorelasi \\
\hline
\end{tabular}

Sumber: Output SPSS (data diolah)

Dari hasil perhitungan dengan SPSS, diperoleh nilai $d$ hitung sebesar 2,109.Dengan menggunakan persamaan $\mathrm{du}<\mathrm{d}<4$ - $\mathrm{dl}$, dumana jika angka d-hitung berada di atas batas (du) dengan kurang dari 4-dl, maka tidak terdapat autokorelasi positif atau negatif.

Untuk melihat tabel, maka digunakan $\mathrm{k}=3, \mathrm{a}=5 \%$ dan $\mathrm{n}=250$, maka $\mathrm{du}=1,808, \mathrm{dl}$ (batas bawah) $=1,776$, nilai DW sebesar 2,109 lebih besar dari batas atas (du) 1,808 dankurang dari 4-1,776 (4-dl), maka dapat disimpulkan tidak terdapat autokorelasi.

\section{Uji Heterokedastisitas}

Pengujian adanya heterokedastisitas dilakukan dengan menggunakan scatterplot yang diperoleh dengan bantuan software SPSS.Heterokedastisitas adalah 
ketidaksamaan varian residual dari suatu model regresi. Uji heterokedastisitas menguji apakah dalam model regresi terjadi ketidaksamaan varian residual dari satu observasi dengan yang lain.

\section{Analisis Regresi Linier Berganda}

Model regresi berganda bertujuan untuk memprediksi besar variabel dependen dengan menggunakan data variabel independen yang sudah diketahui besarnya. Adapun hasil analisis regresi berganda sebagai berikut :

Tabel 4

Koefisien Regresi Tentang Pengaruh Perceived Risk, Service Infrastructure, Acquisition Utility Terhadap Perilaku Berbelanja Online

Coefficients ${ }^{a}$

\begin{tabular}{|lrrrrrrrr|}
\hline & \multicolumn{2}{c}{$\begin{array}{c}\text { Unstandardized } \\
\text { Coefficients }\end{array}$} & \multicolumn{2}{c}{$\begin{array}{c}\text { Standardized } \\
\text { Coefficients }\end{array}$} & \multicolumn{3}{c}{ Collinearity Statistics } \\
Model & $\mathrm{B}$ & \multicolumn{1}{c}{ Std. Error } & Beta & \multicolumn{1}{c}{$\mathrm{t}$} & \multicolumn{1}{c}{ Sig. } & Tolerance & VIF \\
\hline 1 (Constant) & .452 & .219 & & & 2.064 & .040 & & \\
x1 & .099 & .037 & & .114 & 2.675 & .008 & .974 & 1.027 \\
x2 & .645 & .040 & & .694 & 16.116 & .000 & .959 & 1.043 \\
x3 & .100 & .035 & & .122 & 2.829 & .005 & .954 & 1.048 \\
\hline
\end{tabular}

a. Dependent Variable:

$\mathrm{y}$

Sumber : Data Primer

Berdasarkan kepada tabel diatas maka diperoleh model persamaan regresi linier berganda sebagai berikut $: Y=0,452+$ $0,099 X_{1}+0,645 X_{2}+0,100 X_{3}$.

Persamaan di atas menunjukkan bahwa koefisien regresi variabel perceived $\operatorname{risk}\left(\mathrm{X}_{1}\right)=0,099$ ini menunjukkan besarnya pengaruh variabel tersebut terhadap perilaku berbelanja online. Tanda positif menunjukkan koefisien arah hubungan yang positif. Dengan arti setiap ada kenaikan satu satuan variabel perceived risk maka perilaku berbelanja online akan naik sebesar 0,099 kali dengan anggapan faktor yang lain konstan (ceteris paribus).
Koefisen regresi variabel service infrastucture $\left(X_{2}\right)=0,645$. ini menunjukkan besarnya pengaruh variabel tersebut terhadap perilaku berbelanja online. Tanda positif menunjukkan koefisien arah hubungan yang positif. Dengan arti setiap ada kenaikan satu satuan variabel service infrastucture, maka perilaku berbelanja online akan naik sebesar 0,645 kali dengan anggapan faktor yang lain konstan (ceteris paribus).

Koefisen regresi variabel acquisition utility $\left(X_{3}\right)=0,100$. ini menunjukkan besarnya pengaruh variabel tersebut terhadap perilaku berbelanja online. Tanda positif menunjukkan 
koefisien arah hubungan yang positif. Dengan arti setiap ada kenaikan satu satuan variabel acquisition utility, maka perilaku berbelanja online akan naik sebesar 0,148 kali dengan anggapan faktor yang lain konstan (ceteris paribus).

\section{Pembuktian Hipotesis}

Pembuktian hipotesis digunakan untuk melihat pengaruh variabel independen terhadap variabel terikatnya dalam hal ini adalah perilaku berbelanja online. Berdasarkan hasil perhitungan melalui komputer dengan menggunakan program SPSS, maka diperoleh data-data perhitungan sebagai berikut :
Perceived Risk Berpengaruh Terhadap Perilaku Berbelanja Online

Untuk melihat pengaruh perceived risk terhadap perilaku berbelanja online digunakan uji statistik $t$. Uji statistik $t$ bertujuan untuk menguji pengaruh secara parsial antar variabel independen terhadap variabel dependen yang membandingkan $t$ hitung dengan $t$ tabel serta melihat nilai signifikansinya.

Nilai $\mathrm{t}$ hitung $>\mathrm{t}$ tabel dan sig. $\mathrm{t}<\mathrm{a}=$ 0,05, maka $\mathrm{H}_{0}$ ditolak dan $\mathrm{H}_{1}$ diterima. Dan sebaliknya jika nilai $\mathrm{t}$ hitung $<\mathrm{t}$ tabel dan sig. $\mathrm{t}>\mathrm{a}=0,05$, maka $\mathrm{H}_{0}$ diterima dan $\mathrm{H}_{1}$ ditolak.

Hasil pengujian hipotesis pertama pada penelitian ini dapat dilihat pada tabel berikut :

Tabel 5.

Pembuktian Hipotesis Pertama

\begin{tabular}{cccccc}
\hline Variabel Independen & Beta & t hitung & t tabel & Sig. & Keterangan \\
\hline Perceived Risk $\left(\mathrm{X}_{1}\right)$ & 0,114 & 2,675 & 1,969 & 0,008 & Berpengaruh \\
\hline
\end{tabular}

Sumber : Output SPSS (data diolah)

Berdasarkan uji regresi, menghasilkan nilai $\mathrm{t}$ hitung variabel perceived risk sebesar Untuk melihat pengaruh service 2,675 dengan nilai siginifikansi sebesar 0,008. infrastructure terhadap perilaku berbelanja Dengan demikian, $\mathrm{t}$ hitung 2,675 $>\mathrm{t}$ tabel 1,969 dengan signifikansi $0,008<0,05$. Jadi dapat dikatakan $\mathrm{HO}_{1}$ ditolak dan $\mathrm{Ha}_{1}$ diterima. Hal ini menunjukkan bahwa perceived risk berpengaruh positif terhadap perilaku berbelanja online.

Service Infrastructure Berpengaruh Terhadap Perilaku Berbelanja Online online digunakan uji statistik $t$. Uji statistik $t$ bertujuan untuk menguji pengaruh secara parsial antar variabel independen terhadap variabel dependen yang membandingkan $t$ hitung dengan $\mathrm{t}$ tabel serta melihat nilai signifikansinya.

Nilai $\mathrm{t}$ hitung $>\mathrm{t}$ tabel dan sig. $\mathrm{t}<\mathrm{a}=$ 0,05, maka $\mathrm{H}_{0}$ ditolak dan $\mathrm{H}_{1}$ diterima. Dan 
sebaliknya jika nilai $\mathrm{t}$ hitung $<\mathrm{t}$ tabel dan sig. $\mathrm{t}>\mathrm{a}=0,05$, maka $\mathrm{H}_{0}$ diterima dan $\mathrm{H}_{1}$ ditolak.
Hasil pengujian hipotesis kedua pada penelitian ini dapat dilihat pada tabel 4.12 berikut :

Tabel 6.

Pembuktian Hipotesis Kedua

\begin{tabular}{|cccccc|}
\hline Variabel Independen & Beta & t hitung & t tabel & Sig. & Keterangan \\
\hline Service Infrastructure $\left(\mathrm{X}_{2}\right)$ & 0,694 & 16,116 & 1,969 & 0,000 & Berpengaruh \\
\hline
\end{tabular}

Sumber : Output SPSS (data diolah)

Berdasarkan uji regresi, menghasilkan nilai $\mathrm{t}$ hitung variabel service infrastructure sebesar 16,116 dengan nilai siginifikansi sebesar 0,000. Dengan demikian, $t$ hitung $16,116>\mathrm{t}$ tabel 1,969 dengan signifikansi $0,000<0,05$. Jadi dapat dikatakan $\mathrm{H}_{1}$ ditolak dan $\mathrm{Ha}_{1}$ diterima.Hal ini menunjukkan bahwa Service infrastructure berpengaruh positif terhadap perilaku berbelanja online.

Service infrastructure meliputi pengiriman dan kebijakan pengembalian (Sinha, 2012). Menurut responden biaya pengirian terjangkau, adanya keterangan tambahan didalam iklan berupa Contact Person atau hotline center, Tampilan Web menarik, adanya informasi tentang carapertukaran produk, lamanya waktu diperbolehkan untukkembali produk, dan informasi tentang biaya yang terkait denganpengiriman barang kembali ke toko online.

Hal ini sesuai dengan pendapat Teo (2002) yang menyatakan dalam hal pelayanan belanja online, faktor kemudahan pengembalian barang sering menjadi perhatian oleh para pembeli.Pelayanan pengembalian barang dilihat dari carapertukaran produk, lamanya waktu diperbolehkan untukkembali produk, dan biaya yang terkait denganpengiriman barang kembali ke toko online (Shim, Shin, Yong \& Nottingham, 2002).

\section{Acquisition Utility Berpengaruh Terhadap} Perilaku Berbelanja Online

Untuk melihat pengaruh Acquisition utility terhadap perilaku berbelanja online digunakan uji statistik $t$. Uji statistik $t$ bertujuan untuk menguji pengaruh secara parsial antar variabel independen terhadap variabel dependen yang membandingkan $t$ hitung dengan $t$ tabel serta melihat nilai signifikansinya.

Nilai $\mathrm{t}$ hitung $>\mathrm{t}$ tabel dan sig. $\mathrm{t}<\mathrm{a}=$ 0,05, maka $\mathrm{H}_{0}$ ditolak dan $\mathrm{H}_{1}$ diterima. Dan sebaliknya jika nilai $\mathrm{t}$ hitung $<\mathrm{t}$ tabel dan sig. $\mathrm{t}>\mathrm{a}=0,05$, maka $\mathrm{H}_{0}$ diterima dan $\mathrm{H}_{1}$ ditolak.

Hasil pengujian hipotesis ketiga pada penelitian ini dapat dilihat pada tabel 4.13 berikut : 
Tabel 7.

Pembuktian Hipotesis Ketiga

\begin{tabular}{cccccc}
\hline Variabel Independen & Beta & t hitung & t tabel & Sig. & Keterangan \\
\hline Acquisition Utility $\left(\mathrm{X}_{1}\right)$ & 0,122 & 2,829 & 1,969 & 0,005 & Berpengaruh \\
\hline
\end{tabular}

Sumber: Output SPSS (data diolah)

Berdasarkan uji regresi, menghasilkan

acquisition utility berpengaruh positif

nilai $t$ hitung variabel acquisition

terhadap perilaku berbelanja online.

utilitysebesar 2,675 dengan nilai siginifikansi sebesar 0,008. Dengan demikian, $t$ hitung 2,675 > t tabel 1,969 dengan signifikansi 0,000 $<0,05$. Jadi dapat dikatakan $\mathrm{H}_{1}$ ditolak dan $\mathrm{Ha}_{1}$ diterima.Hal ini menunjukkan bahwa

\section{Hasil Uji One Way ANOVA}

Berikut ini adalah hasil statistik deskriptif ANOVA :

Tabel 8.

Hasil Deskriptif ANOVA

\begin{tabular}{|c|c|c|c|c|c|c|c|c|c|}
\hline \multicolumn{10}{|c|}{ Descriptives } \\
\hline & & \multirow[b]{2}{*}{$\mathrm{N}$} & \multirow[b]{2}{*}{ Mean } & \multicolumn{6}{|c|}{$\begin{array}{l}95 \% \text { Confidence } \\
\text { Interval for } \\
\text { Mean }\end{array}$} \\
\hline & & & & $\begin{array}{c}\text { Std. } \\
\text { Deviation }\end{array}$ & $\begin{array}{l}\text { Std. } \\
\text { Error }\end{array}$ & $\begin{array}{l}\text { Lower } \\
\text { Bound }\end{array}$ & $\begin{array}{l}\text { Upper } \\
\text { Bound }\end{array}$ & Minimum & Maximum \\
\hline \multirow[t]{3}{*}{$\mathrm{x} 1$} & Laki-laki & 125 & 43.3280 & 6.42924 & .57505 & 42.1898 & 44.4662 & 27.00 & 51.00 \\
\hline & Perempuan & 125 & 41.3520 & 7.64142 & .68347 & 39.9992 & 42.7048 & 26.00 & 52.00 \\
\hline & Total & 250 & 42.3400 & 7.11639 & .45008 & 41.4536 & 43.2264 & 26.00 & 52.00 \\
\hline \multirow[t]{3}{*}{$x 2$} & Laki-laki & 125 & 49.3280 & 7.41595 & .66330 & 48.0151 & 50.6409 & 32.00 & 60.00 \\
\hline & Perempuan & 125 & 51.5840 & 8.36485 & .74817 & 50.1032 & 53.0648 & 32.00 & 60.00 \\
\hline & Total & 250 & 50.4560 & 7.96932 & .50402 & 49.4633 & 51.4487 & 32.00 & 60.00 \\
\hline \multirow[t]{3}{*}{$x 3$} & Laki-laki & 125 & 54.0800 & 8.27608 & .74024 & 52.6149 & 55.5451 & 33.00 & 64.00 \\
\hline & Perempuan & 125 & 50.5360 & 9.42333 & .84285 & 48.8678 & 52.2042 & 20.00 & 65.00 \\
\hline & Total & 250 & 52.3080 & 9.02680 & .57090 & 51.1836 & 53.4324 & 20.00 & 65.00 \\
\hline \multirow[t]{3}{*}{$\mathrm{y}$} & Laki-laki & 125 & 21.9120 & 3.82061 & .34173 & 21.2356 & 22.5884 & 8.00 & 29.00 \\
\hline & Perempuan & 125 & 23.4400 & 3.14796 & .28156 & 22.8827 & 23.9973 & 14.00 & 29.00 \\
\hline & Total & 250 & 22.6760 & 3.57634 & .22619 & 22.2305 & 23.1215 & 8.00 & 29.00 \\
\hline
\end{tabular}

Sumber : Output SPSS (data diolah)

Berdasarkan hasil statistik deskriptif ANOVA di atas terlihat bahwa perceived risk mahasiswa laki-laki lebih besar dari perceived risk mahasiswa perempuan, dilihat dari nilai mean mahasiswa laki-laki 43,3280 > 41,3520 nilai mean mahasiswa perempuan. Kemudian service infrastructure mahasiswa perempuan lebih besar dari service 
infrastructure mahasiswa laki-laki, dilihat dari nilai mean mahasiswa perempuan 51,5840> 49,3280 nilai mean mahasiswa lakilaki.Selanjutnya acquisition utility mahasiswa laki-laki lebih besar dari acquisition utility mahasiswa perempuan, dilihat dari nilai mean mahasiswa laki-laki 54,0800> 50,5360 nilai mean mahasiswa perempuan.Kemudian perilaku berbelanja online mahasiswa perempuan lebih besar dari perilaku berbelanja online mahasiswa laki-laki, dilihat dari nilai mean mahasiswa perempuan $23,4400>21,9120$ nilai mean mahasiswa lakilaki.

Kemudian untuk melihat perbedaan perilaku berbelanja online ditinjau dari perceived risk mahasiswa laki-laki dengan perempuan, terlihat dari hasil uji ANOVA berikut ini :

Tabel 9.

Hasil Uji ANOVA Variabel Perceived Risk

\begin{tabular}{|ccc|}
\hline Variabel & Sig. & Keterangan \\
\hline Perceived Risk & 0,028 & Terdapat Perbedaan \\
\hline
\end{tabular}

Sumber : Output SPSS (data diolah)

Berdasarkan uji One Way ANOVA pada tabel di atas diketahui bahwa untuk variabel perceived risk nilai signifikansinya sebesar $0,028<0,05$ sehingga $\mathrm{H}_{1}$ diterima atau dengan kata lain terdapat perbedaan perceived risk antara mahasiswa laki-laki dan mahasiswa perempuan.
Untuk melihat perbedaan perilaku berbelanja online ditinjau dari service infrastructure mahasiswa laki-laki dengan perempuan, terlihat dari hasil uji ANOVA berikut ini :

Tabel 10.

Hasil Uji ANOVA Variabel Service Infrastructure

\begin{tabular}{|ccc|}
\hline Variabel & Sig. & Keterangan \\
\hline Service Infrastructure & 0,025 & Terdapat Perbedaan \\
\hline
\end{tabular}

Sumber: Output SPSS (data diolah)

Berdasarkan uji One Way ANOVA pada tabel di atas diketahui bahwa untuk variabel service infrastructure nilai signifikansinya sebesar 0,025 < 0,05 sehingga $\mathrm{H}_{1}$ diterima atau dengan kata lain terdapat perbedaan service infrastructure antara mahasiswa laki-laki dan mahasiswa perempuan.

Kemudian melihat perbedaan perilaku berbelanja online ditinjau dari acquisition utility mahasiswa laki-laki dengan 
perempuan, terlihat dari hasil uji ANOVA berikut ini :

Tabel 11.

Hasil Uji ANOVA Variabel Acquisition Utility

\begin{tabular}{|ccc|}
\hline Variabel & Sig. & Keterangan \\
\hline Acquisition Utility & 0,002 & Terdapat Perbedaan \\
\hline
\end{tabular}

Sumber: Output SPSS (data diolah)

Berdasarkan uji One Way ANOVA pada tabel di atas diketahui bahwa untuk variabel acquisition utility nilai signifikansinya sebesar 0,002 < 0,05 sehingga $\mathrm{H}_{1}$ diterima atau dengan kata lain terdapat perbedaan acquisition utility antara mahasiswa laki-laki dan mahasiswa perempuan.

Kemudian melihat perbedaan perilaku berbelanja online mahasiswa lakilaki dengan perempuan, terlihat dari hasil uji ANOVA berikut ini :

Tabel 12.

Hasil Uji ANOVA Variabel Perilaku Berbelanja Online

\begin{tabular}{|ccc|}
\hline Variabel & Sig. & Keterangan \\
\hline Perilaku Berbelanja Online & 0,001 & Terdapat Perbedaan \\
\hline
\end{tabular}

Sumber : Output SPSS (data diolah)

Berdasarkan uji One Way ANOVA pada tabel di atas diketahui bahwa untuk variabel perilaku berbelanja online nilai signifikansinya sebesar 0,001 < 0,05 sehingga $\mathrm{H}_{1}$ diterima atau dengan kata lain terdapat perbedaan perilaku berbelanja online antara mahasiswa laki-laki dan mahasiswa perempuan.

\section{PEMBAHASAN}

Sebelumnya telah dilakukan pembuktian terhadap hipotesis dengan menghimpun data yang diperoleh dari para responden dan diolah dengan bantuan komputer yaitu program SPSS sehingga dapat dijelaskan pengaruh perceived risk, service infrastructure, acquisition utility dan perilaku berbelanja onlinemahasiswa serta perbedaannya antara laki-laki dengan perempuan, berikut ini dilanjutkan dengan pembahasan hasil analisis.

Perceived risk berarti kenyakinan subyektif individu tentang potensi konsekuensi negatif dari keputusan yang diambil konsumen (Samadi \& Ali, 2009). Perceived risk berarti keyakinan subyektif individu tentang potensi konsekuensi negatif dari keputusan yang diambil konsumen. Resiko yang dirasakan adalah konsep fundamental dan perilaku konsumen yang 
menyiratkan pengalaman konsumen prapembelian dalam ketidakpastian mengenai jenis dan tingkat kerugian yang diperkirakan akibat dari pembelian dan penggunaan produk. Dimensi dari resiko ketika seorang konsumen melakukan pembelian online meliputi resiko produk, resiko financial dan resiko kenyamanan.

Hal ini juga konsisten dengan pendapat Ye Naiyi (2004) yang menyatakan bahwa dimensi perceived risk dalam online shopping adalah fraud risk, delivery risk, financial risk, process dan time risk, product risk, privacy risk, information risk.

Perceived risk adalah penyebab utama mengapa orang enggan berbelanja online. Karena sifatnya yang tidak bertemu secara langsung antara pembeli dan penjual, ecommerce memunculkan persepsi risiko yang berbeda-beda. Ada yang menghawatirkan kehilangan uang, ada yang menghawatirkan faktor waktu pengiriman, ada juga yang mempertimbangkan faktor security dan privacy.

Service infrastructure meliputi pengiriman dan kebijakan pengembalian (Sinha, 2012). Menurut responden biaya pengirian terjangkau, adanya keterangan tambahan didalam iklan berupa Contact Person atau hotline center, Tampilan Web menarik, adanya informasi tentang cara pertukaran produk, lamanya waktu diperbolehkan untuk kembali produk, dan informasi tentang biaya yang terkait dengan pengiriman barang kembali ke toko online.

Hal ini sesuai dengan pendapat Teo (2002) yang menyatakan dalam hal pelayanan belanja online, faktor kemudahan pengembalian barang sering menjadi perhatian oleh para pembeli. Pelayanan pengembalian barang dilihat dari cara pertukaran produk, lamanya waktu diperbolehkan untuk kembali produk, dan biaya yang terkait dengan pengiriman barang kembali ke toko online (Shim, Shin, Yong \& Nottingham, 2002).

Acquisition utility adalah manfaat yang diterima konsumen dalam berbelanja online misalnya, kualitas produk, promosi, biaya (harga) yang dibutuhkan ketika memperoleh produk. Kajian tentang perilaku berbelanja telah ditunjukkan dalam teori bauran pemasaran seperti faktor harga yang merupakan faktor penting yang menentukan keputusan memilih sebuah toko (Gijsbrechts et al 2008; Vroegrijk et al 2013). Seperti telah diketahui bahwa meskipun toko online maupun toko konvensional memiliki rantai yang sama dalam hal harga / kualitas, instrumen bauran pemasaran masih dapat berbeda untuk beberapa alasan (Neslin et al 2006;. Wolk dan Ebling 2010).

Acquisition utility meliputi adanya perbedaan produk, perbedaan harga, perbedaan promosi dan adanya stimuli toko. Menurut responden berbelanja di toko online tersedia pilihan merek untuk produk sejenis, 
transaksi online meningkatkan efisiensi biaya, promosi di toko online menarik perhatian konsumen, gambar yang ada di iklan toko online sangat menarik sehingga tertarik untuk membeli. Hal ini sesuai dengan hasil penelitian Dedy Syahputra Lambe (2014) yang menyatakan bahwa salah satu faktor yang mempengaruhi perilaku keputusan pembelian melalui e-commerce adalah variabel keuntungan berbelanja online yang meliputi pilihan produk yang lebih banyak, penghematan waktu, keuntungan lebih, toko online lebih baik dibandingkan toko fisik, harga yang kompetitif.

\section{KESIMPULAN}

Berdasarkan hasil analisis dan pembahasan sebelumnya, berikut ini dikemukakan beberapa kesimpulan sebagai berikut: (1) hasil pengujian hipotesis pertama menunjukkan bahwa perceived risk berpengaruh positif terhadap perilaku berbelanja online artinya hipotesis pertama diterima, (2) hasil pengujian hipotesis kedua menunjukkan bahwa service infrastructure berpengaruh positif terhadap perilaku berbelanja online artinya hipotesis kedua diterima, (3) hasil pengujian hipotesis ketiga menunjukkan bahwa acquisition utility berpengaruh positif terhadap perilaku berbelanja online artinya hipotesis ketiga diterima, (4) hasil pengujian hipotesis
keempat menggunakan ANOVA
menunjukkan terdapat perbedaan perceived risk, service infrastructure, acquisition utility dan perilaku berbelanja online antara mahasiswa laki-laki dan mahasiswa perempuan. Artinya hipotesis keempat diterima.

\section{Endnotes:}

1 Tjiptono, fandy dan Chandra Gregorius, 2011. Service, Quality and Satisfaction. Edisi 3. Penerbit Andi. Yogyakarta.

2 Sutarman. 2009. Pengantar Teknologi Informasi. Yogyakarta: Bumi Aksara.

3 Suyanto, M. 2003. Strategi Periklanan Pada ECommerce Perusahaan Top Dunia. Yogyakarta : Andi Offset.

4 Samadi, Mansour dan Ali Yaghoob-Nejadi, 2009. A Survey of the Effect of Consumer Perceived Risk on Purchase Intention in E-Shopping. Business Inteligence. Journal. 261-275.

5 Nugroho, Mahendra Adhi. 2009. Model Penerimaan E-Commerce. Jurnal Pendidikan Akuntansi, Vol. VII No. 2.

6 Sitkin, S. B., and Pablo, A. L. 1992. Reconceptualizing the Determinants of Risk Behavior. Academy of Management Review, 17(1), 9-38.

7 Chang, M. K., Cheung, W., and Lai, V. S. (2005). "Literature Derived Reference Models for The Adoption of Online Shopping". Information \& Management, 42(4), 543-559.

8 Pavlou, P. A. Consumer Acceptance of Electronic Commerce: Integrating Trust and Risk with The Technology Acceptance Model. International Journal of Electronic Commerce, 7(3),. Spring 2003, pp. 101-134. Romney, Marshall B. and Paul John Steinbart. 2011

9 Naiyi, Y.E, 2004. Dimmensios of Consumer's Perceived Risk in Online Shopping. Journal of Electronic Scince and Tecnology of China. Vol.2 No 3.

10 Sinha, Jayendra, \& Kim, Jiyeon. 2012, Factors affecting Indian consumers' online buying behavior, Innovative Marketing, Volume 8, Issue 2.

11 Campo, K \& Breugelmans, E. 2015, Buying Groceries in Brick and Click Stores: Category Allocation Decisions and The Moderating Effect of Online Buying Experience, Forthcoming in Journal of Interactive Marketing.

12 Solomon, M. R. 2006. Consumer Behaviour : A European Perspective.3th ed. Pearson Prantice Hall. New Jersey. 
13 Schiffman dan kanuk, 2008. Perilaku Konsumen. Prentice Hall, Inc. Edisi Ketujuh.

14 Kotler, Philip, 2009. Manajemen Pemasaran, PT. Prenhallindo, Jakarta.

15 Suhir, Moch dan Imam Suyadi. 2014. "Pengaruh Persepsi Risiko, Kemudahan dan Manfaat terhadap Keputusan Pembelian secara Online". Jurnal Administrasi Bisnis Vol 8 No. 1. Malang: Fakultas Ilmu Administrasi Universitas Brawijaya.

16 Prabowo dan Suwarsi. 2009. Pengaruh Shopping Orientations dan Gender Differences pada Online Information Search dan Online Purchase, Jurnal Fokus Manajerial,Vol 7 No. 2.

17 Turban, Effraim, Lee, King, dan Chung, 2000. Electronic Commerce : A Managerial Perspective. Person Education Inc., Upper Saddle River New Jersey.

\section{DAFTAR PUSTAKA}

Arikunto, Suharsimi, 2005. Prosedur Penelitian, Jakarta : Rineka Cipta.

Assael, Henry. 1998. Consumer Behavior and Marketing Action. 4th ed. Kent Publishing. Boston.

Ajzen, I, 2002.Perceived Behavioral Control, SelfEfficicacy, Locus of Control and Theory of Planned Behavior. Journal of Applied Social Psychology.

Bae, Soonyong \& Lee, Taesik. 2011. Gender Differences in Consumers' Perception of Online Consumer Reviews, Electron Commer Res, 11, Pp. 201-214

Bungin, Burhan, 2004. Metodologi Penelitian Sosial, Surabaya: Airlangga University Press.

Campo, K\&Breugelmans,E. 2015, Buying Groceries in Brick and Click Stores: Category Allocation Decisions and The Moderating Effect of Online Buying Experience, Forthcoming in Journal of Interactive Marketing.

Chang, M. K., Cheung, W., and Lai, V. S. (2005). "Literature Derived Reference Models for The Adoption of Online

$$
\begin{aligned}
& \text { Shopping". Information } \mathcal{E} \\
& \text { Management, 42(4), 543-559. }
\end{aligned}
$$

Chapra, Umer, 2005. The Future of Economics an Islamic Perspective.Jakarta : Asy Syaamil Press \& Grafika.

Dharmamesta, Basu Swastha dan T. Handoko, 2008. Manajemen Pemasaran: Analisa Perilaku Konsumen. BPFE.Yogyakarta.

Fatah Abdul, 2013. Evaluating Acceptance of Online Purchasing Investigating Factors Influence on Purchasing Intentions.International Journal of Business and Management, Vol. 8 No. 18.

Garbarinoa, Ellen\&Strahilevitz, Michal. 2004. Gender Differences in the Perceived Risk of Buying Online and theEffects of Receiving a Site Recommendation, Journal of Business Research 57, 768- 775

Jen-Hung, Huang \& Yi-Chun, Yang. 2010.Gender Differences in Adolescents' Online ShoppingMotivations, African Journal of Business Management, Vol. 4(6), pp. 849-857

Kartajaya, Hermawan, 2000. Marketing Plus 2000 Siasat Memenangkan Persaingan Global. Jakarta: PT. Gramedia Pustaka.

Kartajaya, Hermawan, 2005. Winning The Mom Market In Indonesia, Strategi Membidik Pasar Ibu. Jakarta: Gramedia Pustaka Utama.

Kertajaya, Hermawan, 2014. Wow Selling. Jakarta: PT Gramedia Pustaka Utama

Koentjaraningrat, 2004, Metode-Metode Penelitian Masyarakat, PT. Gramedia, Jakarta.

Kotler, .Philip, 2009.Manajemen Pemasaran, PT. Prenhallindo, Jakarta. 
Kuncoro, Mudjarad, 2007, Metode Kuantitatif Teori dan Aplikasi untuk Bisnis dan Ekonomi.IPD STIM YKPN, Yogjakarta

Marketeers, Edisi November 2012.

Moleong, Lexy.J, 2005, Metodologi Penelitian Kualitatif, Remaja Rosdakarya, Bandung.

Narbuko, Chalil, Abu Achmadi, 2004, Metodologi Penelitian, Penerbit Bumi Askara, Jakarta.

Naiyi, Y.E, 2004. Dimmensios of Consumer's Perceived Risk in Online Shopping. Journal of Electronic Scince and Tecnology of China. Vol.2 No 3.

Nugroho, Mahendra Adhi. 2009. Model Penerimaan E-Commerce. Jurnal Pendidikan Akuntansi, Vol. VII No. 2.

Pavlou, P. A. Consumer Acceptance of Electronic Commerce: Integrating Trust and Risk with The Technology Acceptance Model. International Journal of Electronic Commerce, 7(3),. Spring 2003, pp. 101-134. Romney, Marshall B. and Paul John Steinbart. 2011

Prabowo dan Suwarsi. 2009. Pengaruh Shopping Orientations dan Gender Differences pada Online Information Search dan Online Purchase, Jurnal Fokus Manajerial,Vol 7 No. 2

Sarwono, J. 2009. Statistik Itu Mudah. Yogyakarta: CV Andi Offset.

Samadi, Mansour dana Ali Yaghoob-Nejadi, 2009. A survey of the Effect of Consumer Perceived Risk on Purchase Intention in E-Shopping.Business

Inteligence.Journal. 261-275.

Santoso, S. 2005. Buku Latihan SPSS Statistik Multivariat. Jakarta: PT Elex Media Komputindo.
Schiffman dan kanuk, 2008. Perilaku Konsumen. Prentice Hall, Inc. Edisi Ketujuh.

Sinha, Jayendra, \&Kim, Jiyeon. 2012, Factors affecting Indian consumers' online buying behavior, Innovative Marketing, Volume 8, Issue 2.

Simamora, Bilson. 2001. ReMarketing For Business Recovery. Jakarta: PT Gramedia Pustaka Utama

Sitkin, S. B., and Pablo, A. L. 1992.Reconceptualizing the Determinants of Risk Behavior. Academy of Management Review, 17(1), 9-38.

Solomon, M. R. 2006. ConsumerBehaviour :A European Perspective.3th ed. Pearson Prantice Hall. New Jersey.

Suyanto, M. 2003. Strategi Periklanan Pada ECommerce Perusahaan Top Dunia. Yogyakarta : Andi Offset.

Sugiyono, 2005.Metode Penelitian Bisnis, Bandung, Alfabeta

Suharso, Puguh, 2010. Model Analisis Kuantitatif. Indeks, Jakarta.

Suhir, Moch dan Imam Suyadi. 2014. "Pengaruh Persepsi Risiko, Kemudahan dan Manfaat terhadap Keputusan Pembelian secara Online". Jurnal Administrasi Bisnis Vol 8 No. 1. Malang: Fakultas Ilmu Administrasi Universitas Brawijaya

Sutarman. 2009. Pengantar Teknologi Informasi. Yogyakarta: Bumi Aksara.

Suyanto, M. 2003. Strategi Periklanan Pada ECommerce Perusahaan Top Dunia.Yogyakarta : Andi Offset.

Tjiptono, fandy dan Chandra Gregorius, 2011.Service, Quality and 
Satisfaction.Edisi 3. Penerbit Andi. Yogyakarta.

Turban, Effraim, Lee, King, dan Chung, 2000.Electronic Commerce : A Managerial Perspective. Person Education Inc., Upper Saddle River New Jersey.

Umar, Husein, 2005, Riset Pemasaran dan Perilaku Konsumen, PT Gramedia Pustaka Utama Bekerjasama dengan Jakarta Business Research Center (JBRC). 